\title{
Trypsin/P Protein Cleavage Reagent
}

National Cancer Institute

\section{Source}

National Cancer Institute. Trypsin/P Protein Cleavage Reagent. NCI Thesaurus. Code C161894.

A protein cleavage reagent comprised of the serine proteinase trypsin/P that cleaves proteins into peptides at the C-terminal side of a lysine or arginine residue. 